Published in final edited form as:

Mass Spectrom Rev. 2014 ; 33(2): 98-109. doi:10.1002/mas.21382.

\title{
THE SUCCINATED PROTEOME
}

\author{
Eric D. Merkley ${ }^{1}$, Thomas O. Metz ${ }^{1}$, Richard D. Smith ${ }^{1}$, John W. Baynes ${ }^{2}$, and Norma \\ Frizzell2,* \\ ${ }^{1}$ Biological Sciences Division, Pacific Northwest National Laboratory, Richland, Washington \\ ${ }^{2}$ Department of Pharmacology, Physiology and Neuroscience, University of South Carolina, \\ School of Medicine, Columbia, South Carolina
}

\section{Abstract}

The post-translational modifications (PTMs) of cysteine residues include oxidation, Sglutathionylation, S-nitrosylation, and succination, all of which modify protein function or turnover in response to a changing intracellular redox environment. Succination is a chemical modification of cysteine in proteins by the Krebs cycle intermediate, fumarate, yielding S-(2succino) cysteine (2SC). Intracellular fumarate concentration and succination of proteins are increased by hyperpolarization of the inner mitochondrial membrane, in concert with mitochondrial, endoplasmic reticulum (ER) and oxidative stress in 3T3 adipocytes grown in high glucose medium and in adipose tissue in obesity and diabetes in mice. Increased succination of proteins is also detected in the kidney of a fumarase deficient conditional knock-out mouse which develops renal cysts. A wide range of proteins are subject to succination, including enzymes, adipokines, cytoskeletal proteins, and ER chaperones with functional cysteine residues. There is also some overlap between succinated and glutathionylated proteins, suggesting that the same low $\mathrm{pK}_{\mathrm{a}}$ thiols are targeted by both. Succination of adipocyte proteins in diabetes increases as a result of nutrient excess derived mitochondrial stress and this is inhibited by uncouplers, which discharge the mitochondrial membrane potential $\left(\Delta \Psi_{\mathrm{m}}\right)$ and relieve the electron transport chain. 2SC therefore serves as a biomarker of mitochondrial stress or dysfunction in chronic diseases, such as obesity, diabetes, and cancer, and recent studies suggest that succination is a mechanistic link between mitochondrial dysfunction, oxidative and ER stress, and cellular progression toward apoptosis. In this article, we review the history of the succinated proteome and the challenges associated with measuring this non-enzymatic PTM of proteins by proteomics approaches.

\section{Keywords}

chemical modification of proteins; cysteine; diabetes; fumarate; succination 


\section{INTRODUCTION}

Cysteine and tryptophan are the least common amino acids in eukaryotic proteins, perhaps because of their sensitivity to oxidation. However, in contrast to tryptophan, cysteine is often exposed on the surface or in active sites of proteins. The free thiol group of cysteine and glutathione has a $\mathrm{p} K_{\mathrm{a}}$ of $\sim 9$, while the $\mathrm{p} K_{\mathrm{a}}$ of active site cysteines in enzymes may be as low as 3-4; in this case, cysteine exists predominantly in the thiolate form and is a fairly reactive nucleophile. Other articles in this volume address the reactivity of cysteine with lipid-derived electrophiles and reactive nitrogen and oxygen species. We focus on the Michael addition reaction of cysteine with the Krebs cycle intermediate, fumarate, to form $S$-(2-succino)cysteine (2SC; Fig. 1). This reaction is termed succination, and the term succino in the descriptor serves to distinguish succination from succinylation, which yields an acid-labile, biologically reversible, ester, thioester, or thioamide derivative of protein. In contrast to succinylated amino acids, the thioether bond of $2 \mathrm{SC}$ is stable to acid hydrolysis and, to the best of our knowledge, is physiologically irreversible. Succination appears to be specific for cysteine, as we have been unable to detect succination of other candidate nucleophilic amino acids, $\mathrm{N}$-acetyllysine or $\mathrm{N}$-acetylhistidine, in incubations at pH 5-10 in vitro, nor were we able to detect modified lysine or histidine residues by dynamic searching of tryptic digests of peptides from adipocyte proteins. Further, incubation of native bovine pancreatic ribonuclease A (RNase) with $500 \mathrm{mM}$ fumarate for $24 \mathrm{hr}$ did not yield an increase in the molecular weight of the protein, measured by MALDI-TOF mass spectrometry. RNase has no free cysteine residues, but has low $\mathrm{p} K_{\mathrm{a}}$ lysine and histidine residues in its active site, which are reactive with other electrophiles, such as iodoacetic acid (Gundlach, Stein, \& Moore, 1959) and carbonyl compounds (Brock et al., 2003). In this article, we present an overview of succination of cysteine residues in protein, discuss the possible roles of succination in regulatory biology, and outline some of the challenges associated with measuring this non-enzymatic post-translational modification (PTM) of proteins by mass spectrometric techniques (Blatnik et al., 2008; Frizzell et al., 2009; Ternette et al., 2013).

\section{SUCCINATION OF PLASMA AND MUSCLE PROTEINS}

The initial identification of $2 \mathrm{SC}$ in tissue proteins was serendipitous. We were studying chemical modification of proteins by advanced glycation end-products (AGEs) in diabetes, searching for $S$-(carboxymethyl)- and $S$-(carboxyethyl)cysteine (CMC, CEC), the thiol analogues of the AGEs, $N^{\varepsilon}$-(carboxymethyl)-and $N^{\varepsilon}$-(carboxyethyl)-lysine (CML, CEL) (Goh \& Cooper, 2008). To normalize CMC to the free cysteine content of protein, we proposed to measure total free sulfhydryl groups in protein by reaction of the denatured, unreduced protein with $N$-(ethyl) maleimide (NEM). The free cysteine content of protein was then measured as $S$-(2-succinyl)cysteine, following acid hydrolysis of the protein (2SC; Fig. 1). In fact, we found and quantified CMC (Alt et al., 2004), and another laboratory subsequently described CEC (Mostafa et al., 2007). However, our proposed standard, 2SC, was unexpectedly detected in native proteins, prior to reaction with NEM. Fumarate seemed the logical endogenous precursor of 2SC. 
$S$-(2-succino)cysteine (2SC) was originally detected in plasma proteins, including albumin, where it represents approximately $3.5 \%$ of total albumin and $10 \%$ of the non-

mercaptalbumin fraction in normal plasma (Alderson et al., 2006). Succinated proteins were also detected in skeletal muscle, and a significant ( 3.5 -fold) increase in succination of total skeletal (gastrocnemius) muscle protein was observed in streptozotocin-induced diabetic rats, a model of type 1 diabetes (Blatnik et al., 2008). The increase in 2SC was correlated with an increase in fumarate concentration in diabetic muscle. The glycolytic enzyme, glyceraldehyde-3-phosphate dehydrogenase (GAPDH), was identified as a major target of succination in diabetic muscle, and succinated GAPDH has been detected in several studies of the succinated proteome in other cells and tissues (below). GAPDH is a tetrameric enzyme with 4 cysteines per subunit, two of which are low $\mathrm{p} K_{\mathrm{a}}$ sulfhydryl groups: Cys-149, in the active site, and Cys-244. Modification of either of these cysteines is known to inactivate the enzyme (Ishii et al., 2003; Maller, Schröder, \& Eaton, 2011).

Succinated GAPDH was detectable at low levels in control muscle and in enzyme from commercial sources, but increased to $\sim 20 \%$ of GAPDH in diabetic muscle. In vitro, the initial rate of succination of GAPDH at pH 7.4 was $~ 250$ times faster than that of $N$ acetylcysteine, consistent with preferential modification of the low $\mathrm{p} K_{\mathrm{a}}$ cysteine residues, which was confirmed by MS analysis of peptides (Blatnik et al., 2008; Blatnik, Thorpe, \& Baynes, 2008). Succination of GAPDH was limited to the low $\mathrm{p} K_{\mathrm{a}}$ residues; the other two cysteine residues were not significantly modified, even after $24 \mathrm{hr}$ incubation in $1 \mathrm{M}$ fumarate, emphasizing the selectivity of succination of proteins. Glutathione did not inhibit succination of GAPDH in vitro, probably because of its much higher $\mathrm{p} K_{\mathrm{a}}$, compared to the target cysteines in GAPDH.

In his unifying hypothesis on the origin of diabetic complications (Brownlee, 2005), Brownlee proposed that partial inactivation of GAPDH by reactive oxygen species (ROS) could explain the activation of several pathways implicated in development of diabetic complications, including the polyol, hexosamine, and protein kinase $\mathrm{C}$ pathways and formation of AGEs. While oxidative stress is certainly relevant to the development of diabetic complications, succination, rather than oxidation, of GAPDH was quantitatively sufficient to explain the decrease in specific activity of the enzyme in diabetic muscle.

\section{SUCCINATION OF ADIPOCYTE PROTEINS}

Adipose tissue and adipocytes play a central role in the development of insulin resistance and diabetes. In both obesity and diabetes, changes in secretion of adipokines, such as adiponectin and leptin, and other inflammatory mediators have systemic effects on metabolism and contribute to development of diabetic cardiovascular disease, morbidity, and mortality (Van Gaal, Mertens, \& De Block, 2006; Shah, Mehta, \& Reilly, 2008). Lai and Goldman reported (Lai \& Goldman, 1992) that, when grown in high glucose (HG: 25 $\mathrm{mM}$ glucose) medium, mouse 3T3-L1 adipocytes secrete several Krebs cycle intermediates, including fumarate, into the medium. More recently, we observed that intracellular fumarate concentration increases $\sim 5$-fold in mature adipocytes grown in HG vs. normal glucose (NG: $5 \mathrm{mM}$ ) medium, with a corresponding increase in 2SC in adipocyte proteins (Nagai et al., 2007). Similar increases and patterns of succination of proteins were observed in 
epididymal, subcutaneous, and mesenteric adipocytes of the $\mathrm{db} / \mathrm{db}$ (leptin receptor deficient) obese mouse, an animal model of type 2 diabetes (Frizzell et al., 2009). Succination was also increased in adipose tissue of the ob/ob (leptin deficient) mouse, and to a lesser extent in the Diet Induced Obese (DIO) mouse, which is an insulin resistant, but not frankly diabetic mouse (Thomas et al., 2012).

A limited spectrum of approximately 60 succinated proteins was detected by Western blotting analysis of adipocytes grown in HG medium (Nagai et al., 2007) (Fig. 2) consistent with the low $(\sim 2.5 \%)$ frequency of cysteine-containing proteins in the proteome (Hu et al., 2010). Further analyses identified 13 of these succinated proteins after antibody overlay of 2D-SDS-PAGE gels and LC-MS/MS analysis; among those were several cytoskeletal proteins (actin, tubulin, tropomyosin, vimentin), chaperones (GRP78/BiP, HSP70, HSP90, and proline-4-hydroxylase/protein disulfide isomerase (PDI)), two enzymes (GAPDH and cathepsin B), two proteins involved in lipid metabolism (annexin and FABP4), and adiponectin (Table 1) (Nagai et al., 2007). All of these proteins have free sulfhydryl groups, several of which are known to be reactive with endogenous electrophiles.

Adiponectin (Adn) was the major succinated protein detected in adipocytes by Western blotting analysis (Frizzell et al., 2009). It is a homopolymeric protein, assembled by a complex pathway in the ER (Liu et al., 2008; Liu \& Liu, 2010). Both total and highmolecular-weight (HMW) isoforms of Adn are decreased in plasma of type 2 diabetic patients, and hypoadiponectinemia is implicated in the development of systemic insulin resistance (Giannessi, Maltinti, \& Del Ry, 2007; Chang et al., 2009). Adn has two cysteine residues, one of which, Cys-39, is involved in covalent crosslinking of monomers. Succinated Adn was not detectable by Western blotting analysis of adipocytes grown in 5 $\mathrm{mM}$ glucose or in adipose tissues of $\mathrm{db} / \mathrm{db}$ heterozygous (non-diabetic) mice, but accounted for 7-8\% of Adn in adipocytes grown in HG medium and in adipose tissue of $\mathrm{db} / \mathrm{db}$ mice (Frizzell et al., 2009). In both cases succination was restricted to the monomeric form of Adn. Further, succinated Adn was not detected in the culture medium or in diabetic plasma. Cys-39 was identified as the site of succination of Adn in adipocytes, so that succination of Cys-39 appeared to inhibit incorporation of Adn monomer into the polymeric, secreted forms of the protein, consistent with the decrease in plasma Adn in diabetes (Frizzell et al., 2009).

Table 1 documents a new list of 31 succinated proteins recently identified in $30 \mathrm{mM}$ glucose treated adipocytes after either strong cation exchange or high $\mathrm{pH}$ fractionation followed by capillary LC-MS/MS. Five of these recent identifications overlap with previously detected succinated proteins, confirming their identity (Nagai et al., 2007; Blatnik et al., 2008). Within this new list there are at least 10 enzymes or enzyme subunit components that are succinated ( $\sim 30 \%$ of identifications), suggesting that succination may affect important regulatory pathways with in the diabetic adipocyte. Future studies will elucidate the significance of these succination sites. 


\section{PATHWAYS AFFECTING SUCCINATION OF PROTEINS-RELATIONSHIP TO MITOCHONDRIAL STRESS}

Oxidative stress is frequently presented as the central cause of mitochondrial dysfunction associated with alterations in the electron transport chain. However, it is evident that other redox changes are occurring simultaneously and in the following sections we describe how succination is linked to redox, oxidative, and endoplasmic reticulum (ER) stress in diabetes, suggesting that fumarate is a novel mediator of metabolic stress in diabetes.

\section{A. Redox Stress}

Figure 3 outlines our current understanding of the mechanisms involved in increased succination of adipose tissue proteins (Frizzell et al., 2012). According to this scheme, excess glucose in diabetic plasma (or in HG medium) exceeds the energy needs of the adipocyte. The resultant increase in the steady-state concentration of ATP and decrease in ADP limit mitochondrial ATP synthase activity, leading to an increase in mitochondrial membrane potential, $\Delta \Psi_{\mathrm{m}}$, which inhibits electron transport by feedback mechanisms (respiratory control). The increase in mitochondrial NADH:NAD ${ }^{+}$(pseudohypoxia) inhibits Krebs cycle dehydrogenases, leading to intramitochondrial accumulation of fumarate (and other Krebs cycle intermediates). Fumarate equilibrates through dicarboxylic acid transporters in the inner mitochondrial membrane into extramitochondrial compartments, modifying proteins throughout the cell (Nagai et al., 2007) (Table 1). The increase in fumarate may also be enhanced by hypoxia in adipose tissue in obesity (Wood et al., 2009; Yin et al., 2009).

As a test of the mechanism outlined in Figure 3, we have shown that the uncouplers of oxidative phosphorylation, dinitrophenol, $\mathrm{CCCP}$ and salicylate, reduce fumarate concentration in adipocytes grown in HG medium, with a corresponding decrease in succination of proteins. Metformin, which at high (supra-pharmacological) concentrations is an inhibitor of Complex 1 in the electron transport chain, also caused an increase in fumarate and succination of proteins. Endogenously, uncoupling proteins may limit the increase in succination of proteins during mitochondrial stress. In fact, succination of proteins in brown adipose tissue was not increased in a squirrel model of obesity (Thomas et al., 2012).

To date we have not detected increased succination of proteins in type 2 diabetic tissues other than in adipose tissue (Thomas et al., 2012), suggesting the significant increase in 2SC in the adipocyte is uniquely linked to adipocyte metabolism. While adipose tissue is a metabolically active endocrine organ that regulates the storage and release of a large amount of energy, its oxygen consumption is $\sim 1 \%$ of brain and $\sim 10 \%$ of resting skeletal muscle per kg wet weight (Frayn, Humphreys, \& Coppack, 1995). Therefore, when presented with nutrient excess in the form of glucotoxicity, it may rapidly achieve its maximal respiratory capacity, initiating the sequence of events described in Figure 3.

Although protein succination in adipocytes accumulates over time (days) when matured in high glucose (Frizzell et al., 2009), it can be reduced when the high glucose is removed and 
cells are switched to normal glucose $(5 \mathrm{mM})$ concentrations. This indicates that succinated proteins are turned over within the adipocyte (Frizzell et al., 2012). The fact that succinated adiponectin is not secreted into the medium of diabetic adipocytes also suggests that nonfunctional succinated proteins are slowly removed intracellularly (Frizzell et al., 2009).

\section{B. Oxidative Stress}

There are significant increases in oxidative stress of mitochondrial origin in adipocytes grown in HG medium (Lin et al., 2005) and similar increases in oxidative stress, in both adipose tissue and systemically in obesity (de Ferranti \& Mozaffarian, 2008); in the latter case, this may reflect ongoing ischemic reperfusion injury or macrophage homing to adipose tissue in obesity. There is significant overlap between the subsets of proteins with cysteine residues susceptible to succination and glutathionylation (Table 1), (Nagai et al., 2007; Townsend, 2007; Frizzell et al., 2009). While the effects of succination on many of these proteins remains to be explored our studies on GAPDH suggest that Cys 149 succination is irreversibly inhibited (Blatnik et al., 2008), whereas glutathionylation has been shown to reversibly inhibits the same Cys 149 of GAPDH in Arabidopsis thaliana, instead protecting it from further irreversible oxidation (Bedhomme et al., 2012). Further, oxidation of GAPDH in our laboratory with limited concentrations of $\mathrm{H}_{2} \mathrm{O}_{2}$, such that the cysteine residues are converted to sulfenic acids, detected by reactivity with dimedone (Kettenhofen \& Wood, 2010), inhibits succination of the protein in vitro (unpublished). This suggests that sulfenation, which can lead to glutathionylation, and succination may be competing processes. Glutathionylation is both protective and reversible, while, to the best of our knowledge, succination is an irreversible modification of protein $2 \mathrm{SC}$ is excreted in rat urine, independent of diets containing succinated proteins, suggesting that $2 \mathrm{SC}$ is neither absorbed nor recycled in vivo (Alderson et al., 2006).

The relationship between succination and oxidative stress is complex, because processes that are associated with succination are also associated with oxidative stress. For example, uncouplers decrease both succination and oxidative stress in adipocytes, while insulin resistance leads to increased succination and oxidative stress. Chelators, which inhibit production of ROS by Fenton reactions, do not inhibit succination, but the effects of radicalscavenging antioxidants on succination have not been reported. The results of these studies will be interesting: antioxidants may inhibit oxidative damage and formation of sulfenic acids without affecting the high mitochondrial fumarate concentration and resultant increase in succination of proteins.

\section{Endoplasmic Reticulum (ER) Stress}

The adipocyte grown in HG and adipose tissue in diabetes are paradigms for the study of metabolic stress - mitochondrial, oxidative, and ER stress. In addition to the alterations in mitochondrial metabolism that lead to succination and oxidative stress, the diabetic adipocyte is subject to ER stress, responds with the unfolded protein response (UPR), and undergoes increased apoptosis (Kallen et al., 2009). Although the mechanism underlying the increase in ER stress in the diabetic adipocyte has not been delineated, the relationship between succination and ER stress is evident from the observation that 3 of the 14 succinated proteins identified in early screens of adipocytes (Nagai et al., 2007) were ER 
chaperones/folding proteins (heat shock protein $90 \beta$ (GRP94/endoplasmin), glucoseregulated protein 78 (GRP78/BiP) and PDI. In recent studies (unpublished), we have determined that succination inhibits the insulin-folding activity of PDI. This is significant, given that one third of the mammalian proteome enters the secretory pathway (Kanapin et al., 2003) and up to $30 \%$ of nascent proteins may need re-folding (Schubert et al., 2000). We propose that inhibition of these ER chaperones by succination of active site thiols might directly contribute to development of ER stress and induction of the UPR.

In addition to direct effects of succination on ER chaperones, we have also observed that the ER stress inhibitors, 4-phenylbutyric acid (PBA) and tauroursodeoxycholic acid (TUDCA), inhibit succination of proteins (unpublished). Unexpectedly, these compounds, at the high concentrations used to demonstrate their effects on ER stress, also act as uncouplers and decrease $\Delta \Psi_{\mathrm{m}}$, supporting a mechanistic relationship between mitochondrial dysfunction and ER stress.

\section{PROTEIN SUCCINATION IN FUMARATE HYDRATASE-DEFICIENT RENAL TUMORS}

In contrast to the increase in fumarate and protein succination observed as a result of glucotoxicity in diabetes, there are massive increases in protein succination in hereditary leiomyomatosis and renal cell cancers (HLRCC) resulting from mutations in fumarate hydratase (FH) (Fig. 5). Mutations in FH lead to elevated fumarate levels in these cancers (Pollard et al., 2005), and fumarate is increasingly recognized as an "oncometabolite" in HLRCC; a component of normal metabolism whose accumulation leads to metabolic dysregulation, priming cells for oncogenesis (Yang et al., 2012b). Increased protein succination was initially detected in a renal-specific fumarase deficient mouse model (Pollard et al., 2007) and was then confirmed to be a marker of FH deficiency in HLRCC in a panel of human tissues (Bardella et al., 2011). The striking increase in 2SC due to the elevated fumarate levels makes protein succination a unique biomarker of $\mathrm{FH}$ deficient cancers.

Further analyses of FH deficient cancers revealed that Kelch-like ECH-associated protein 1 (KEAP1) is a major succinated protein target (Adam et al., 2011; Ooi et al., 2011). KEAP1 was succinated on two critical cysteine residues (Cys 151 and Cys 288), which disrupts its interaction with the nuclear factor (erythroid-derived 2)-like 2 (Nrf2) transcription factor. Consequently, Nrf2 is stabilized in the nucleus and binds to the antioxidant response element (ARE) to upregulate the expression of antioxidant pathways (Nguyen, Nioi, \& Pickett, 2009; Zhang, 2010; Mitsuishi, Motohashi, \& Yamamoto, 2012). Nrf2 stabilization has also recently been linked to altered glucose and glutamine metabolism, suggesting that succination of KEAP1 may directly play a role in the metabolic reprogramming that contributes to cancer cell proliferation (Mitsuishi et al., 2012). In other work, the activation of the Nrf2 antioxidant pathway by fumarate appears to be cardioprotective in cardiac FH deficiency (Ashrafian et al., 2012), providing evidence that succination of KEAP1 may relieve oxidative stress during ischemia/reperfusion injury. 
Pollard et al. have recently identified 93 succinated proteins in FH deficient fibroblasts and renal cysts (Ternette et al., 2013). This list is significantly larger than the adipocyte succinated proteome in Table 1. Although the longer list is consistent with the significantly higher levels of fumarate in the FH mutant cells, improvements in detection may also be attributed to sample enrichment by analysis of specific subcellular fractions and analysis of excised 1D-SDS-PAGE slices that were positive for succination. Within this list, 32 of 93 proteins are enzymes $(\sim 34 \%)$ and at least 5 proteins are succinated in known functional sites. Aconitase 2, the Krebs cycle enzyme that catalyzes the isomerization of citrate to isocitrate, was succinated on three cysteine residues. All three of these cysteines (Cys 385, Cys 451, and Cys 458) are essential for iron-sulfur cluster binding and their succination resulted in a significant reduction in enzyme activity both in vitro and in vivo.

Other possible targets, deserving further study, include nuclear transcription factors, whose detection would be limited by their low copy number in the cell. Transcription factors, as a group, have essential cysteine residues and are inactivated by oxidation of cysteine and by thiol reagents (Webster, Prentice, \& Bishopric, 2001; Cross \& Templeton, 2006). Zinc finger proteins have zinc-coordinated cysteine sulfhydryl residues, not too different from the iron coordination sites in aconitase.

\section{RELATIONSHIP OF SUCCINATION TO ALKYLFUMARATE MODIFICATION OF PROTEINS}

The alkylfumarate esters, monomethylfumarate (MMF) and dimethlyfumarate (DMF), are used in treatment of psoriasis and neurological conditions such as multiple sclerosis (Mrowietz et al., 2007; Papadopoulou et al., 2010). These fumarate esters rapidly enter the cell where they react with available thiols, including glutathione (Schmidt \& Dringen, 2010). As a result of its reactivity with glutathione DMF rapidly induces an Nrf2-mediated antioxidant response in neurons, replenishing intracellular glutathione levels and promoting beneficial changes in the inflammatory cell phenotype. Treatment with DMF leads to upregulation of heme oxygenase 1 and induction of Type II dendritic cells, reducing the local inflammatory profile (Ghoreschi et al., 2011). These effects are mediated in part by direct succination of sulfhydryl groups in Keap1 by DMF (Linker et al., 2011). Although both fumarate and DMF treatment result in modification of cysteine residues in protein, the fumarate esters are more reactive, and therefore less selective than fumarate in modifying protein thiols and glutathione, while fumarate is slow to react and more specific for reactive thiolates (in preparation). Alkylfumarates have a pronounced effect on the cellular antioxidant response which appears to be beneficial in neurological conditions with an inflammatory component. It seems possible that fumarate may also participate in activation of the antioxidant response in adipocytes in response to glucotoxicity.

\section{CHALLENGES OF MASS SPECTROMETRIC ANALYSIS OF SUCCINATED PROTEINS}

A key challenge in detecting and identifying succinated proteins by LC-ESI-MS-based bottom-up proteomics analysis is that of finding a low-abundance PTM in a complex 
sample. The chance of detecting a peptide from a low-abundance protein species in samples of high complexity (e.g., blood plasma, total cell lysates) is reduced in two ways. First, peptides from more abundant protein species compete for the limited number of protons during the ESI process, suppressing the ionization of peptides from low abundance species. Second, peptides from less abundant protein species are less likely to be chosen for MS/MS analysis during data-dependent acquisition of tandem mass spectra (i.e., "under sampling"). General sample complexity can be partly addressed by fractionating the sample prior to LCMS analysis using any separation method that is orthogonal to traditional reversed-phase chromatography, such as strong cation exchange chromatography (SCX) (Washburn, Wolters, \& Yates, 2001; Mohammed \& Heck, 2011) or high-pH reversed-phase chromatography (Yang et al., 2012a). However, fractionation alone may be insufficient for improving the coverage of low abundance PTMs. Previous bottom-up proteomics studies of other low abundance PTMs, for example protein phosphorylation (Beltran \& Cutillas, 2012), non-enzymatic glycation (Zhang et al., 2007), and heme $c$ modification (Merkley et al., 2012), have shown that the best strategy for detection of rare PTMs is enrichment, for example by using antibody or chemical methods. A successful enrichment strategy is tailored to the physical and chemical properties of the PTM to create a strong interaction, for example, a metal-ligand coordination interaction for heme peptides and phosphopeptides, and a reversible covalent complex with boronic acid in the case of non-enzymatically glycated peptides. The challenge for succination is that its distinctive chemical functional groups, carboxylic acids, are also naturally present in peptides in the form of aspartyl and glutamyl residues and the carboxy terminal amino acid, making a strictly chemical enrichment difficult. The polyclonal antibodies to 2SC that have been developed thus far work well for Western immunoblotting (Nagai et al., 2007; Frizzell et al., 2009, 2012), but they do not work for enrichment of succinated proteins or peptides on affinity columns or protein-A sepharose beads. This suggests that the antibodies recognize an extended or denatured conformation assumed by the succinated protein after transfer to the blotting membrane, rather than a solution conformation (N. Frizzell, unpublished). One other approach that we are still exploring is analysis of specific subcellular fractions, such as the mitochondrial, ER, or cytosolic fractions. This approach reduces the complexity of the protein matrix, and succinated proteins have already been identified in all of these subcellular compartments (Table 1).

Another challenge in proteomic analyses of succinated peptides using LC-MS/MS is that of identification, rather than detection. The stochastic nature of data-dependent acquisition in bottom-up proteomics, the specifics of gas-phase fragmentation chemistry, and the vagaries of peptide identification by database searches can lead to cases where a peptide of interest is detected and even fragmented but not identified. For instance, collision-induced dissociation of non-enzymatically glycated peptides typically yields mostly neutral losses of water from the precursor ion rather than useful sequence-specific ions, precluding peptide identification (Zhang et al., 2007). This problem was surmounted by employing electron transfer dissociation. Similarly, if $2 \mathrm{SC}$ affects fragmentation behavior in a way that results in poor fragmentation, sequence information may be lost. This problem could be assessed by manual inspection of LC-MS/MS data on model proteins succinated in vitro. 
Informatics issues can also complicate identification. The mass of the 2SC modification $\left(\mathrm{C}_{4} \mathrm{O}_{4} \mathrm{H}_{4}, 116.011 \mathrm{Da}\right)$ is $\sim 2 \mathrm{Da}$ less than the mass of two carbamidomethylation modifications $\left(2 \times \mathrm{C}_{2} \mathrm{H}_{3} \mathrm{NO}, 2 \times 57.021 \mathrm{Da}=114.042 \mathrm{Da}\right)$ resulting from alkylation with iodoacetamide in peptides with two cysteine residues. Fragmentation spectra of peptides with two or more cysteines often score very highly for both the succinated peptide or the doubly carbamidomethylated peptide (unpublished data). As illustrated in Figure 4, the only way to distinguish between these two possibilities is by comparing theoretical and observed precursor masses. An $\sim 2$-Da mass difference may be difficult to resolve for low-resolution mass spectrometers if the peptide is multiply charged. Even for high resolution mass spectrometry, deisotoping algorithms can erroneously choose the second or third isotopic peak, resulting in a 1- or 2-Da error in the reported precursor mass for multiply charged peptides. Thus, automated data analysis pipelines sometimes apply a correction of -1 or -2 $\mathrm{Da}$ when the absolute mass error is close to 1 or $2 \mathrm{Da}$, respectively, before calculating the relative mass measurement accuracy in ppm. Thus, we have found it necessary to filter potential succinated peptide-spectrum matches by the absolute mass measurement accuracy to eliminate doubly carbamidomethylated peptides. A more effective alternative strategy, applicable for those MS/MS search engines that allow multiple modifications on a single residue, is to treat cysteine carbamidomethylation as a static modification with mass 57.0215 $\mathrm{Da}$ and cysteine succination as a dynamic modification with a mass of $58.9895 \mathrm{Da}$, which is the difference between the succination and carbamidomethylation modification masses. This approach increases the specificity of the search by reducing the number of peptides considered for each spectrum. In general, we recommend that caution be exercised in interpreting MS/MS spectra of putative succinated peptides, especially those obtained with low-resolution instrumentation, and for samples alkylated with iodoacetamide. High mass measurement accuracy instrumentation (e.g., Orbitrap instruments) should be used in analyses of succinated peptides prepared in this manner whenever possible. It is also advisable to use an alternative alkylating agent, such as vinyl pyridine.

It has been suggested that the carboxylate moieties of $2 \mathrm{SC}$ would carry negative charges, thus reducing the net positive charge of the succinated peptides and preventing their efficient ionization. The $\mathrm{p} K_{\mathrm{a}}$ values of succinate are 4.21 and 5.64, and that of formic acid, a commonly used ion-pairing reagent in $\mathrm{LC}$, is 3.75 (Haynes, 2012). The $\mathrm{pH}$ of a $0.1 \%$ formic acid solution is therefore $\sim 2.7$. It can be shown, using the Henderson-Hasselbalch equation, that only $3 \%$ of the carboxylic groups of the succinated peptide are deprotonated at this $\mathrm{pH}$, which is also the $\mathrm{pH}$ of the electrospray process. Thus, the charge carried by succinated peptides is likely to be similar to that of unmodified peptides.

\section{CONCLUSION}

Cysteine residues in protein are subject to a wide range of modifications by endogenous electrophiles and ROS of both enzymatic and non-enzymatic origin. These reactive compounds increase in tissues during oxidative stress and inflammation, stimulate the antioxidant response element (ARE), and have broad effects on cell signaling cascades and metabolism. Succination is a relatively specific reflection of mitochondrial stress, the result of inhibition of electron transport and tricarboxylic acid cycle activity. Because of the central role of mitochondria in cellular metabolism, succination interfaces with oxidative 
and ER stress; 2SC is a biomarker of complex cellular dysfunction. In comparison with other electrophiles, such as hydroxyalkenals and carbonyl compounds, fumarate is a relatively weak electrophile. For this reason, it is more selectively focused on functional, low $\mathrm{p} K_{\mathrm{a}}$ cysteine residues in proteins. In contrast, hydroxyalkenals derived from lipid peroxidation chemistry react with cysteine, lysine and histidine residues in protein, and carbonyls derived from glycation and lipoxidation chemistry react with cysteine, lysine and arginine. In many cases, because of the reactivity of the nucleophiles, the chemical modifications are distributed among a range of amino acids in the protein, while succination is amino acid-specific and targeted at critical cysteine residues. A similar analogy applies to oxidative modification of proteins; intracellular oxidants, such as peroxides and hypochlorous acid, are relatively reactive, yielding not only sulfenic acids, but a number of other amino acid oxidation products, including tryptophan degradation products and protein carbonyls, such as hydroxylated amino acids and amino acid semialdehydes. Further elaboration of the succinated proteome and measurement of the extent of modification of specific proteins should provide novel insights into the role for succination in regulatory biology.

\section{Acknowledgments}

Contract grant sponsor: National Institutes of Diabetes, Digestive and Kidney Diseases Research Grants; Contract grant numbers: DK071283, DK19971; Contract grant sponsor: American Diabetes Association Junior Faculty Award; Contract grant number: 1-11-JF-13; Contract grant sponsor: NIH NIGMS P41 BTRC; Contract grant numbers: RR185220, GM103493-10.

Research Grants DK071283 (T.O.M.) and DK19971 (J.W.B.) from the National Institutes of Diabetes, Digestive and Kidney Diseases, and American Diabetes Association Junior Faculty Award 1-11-JF-13 (N.F.). Proteomics analyses were supported by the NIH NIGMS P41 BTRC (RR185220 and GM103493-10; R.D.S.) and were performed in the Environmental Molecular Sciences Laboratory, a U.S. Department of Energy (DOE) national scientific user facility at Pacific Northwest National Laboratory (PNNL). PNNL is a multi-program national laboratory operated by Battelle Memorial Institute for the DOE under Contract No. DE-AC06-76-RLO-1830. The authors thank Erika M. Zink and Karl K. Weitz of PNNL for preparation and analysis of proteomics samples, respectively. We also thank David G. Camp II of PNNL for helpful discussions and for facilitating the proteomics work.

\section{ABBREVIATIONS}

$\begin{array}{ll}\text { 2SC } & S \text {-(2-succino)cysteine } \\ \text { AGE } & \text { advanced glycation end-product } \\ \text { ALE } & \text { advanced lipoxidation end-product } \\ \text { CML } & N \text {-(carboxymethyl)lysine } \\ \text { GAPDH } & \text { glyceraldehyde-3-phosphate dehydrogenase } \\ \text { GSH } & \text { GSSG, reduced and oxidized glutathione } \\ \text { HG } & \text { high glucose (medium) } \\ \text { ROS } & \text { reactive oxygen species } \\ \Delta \Psi_{\mathbf{m}} & \text { mitochondrial membrane potential }\end{array}$




\section{References}

Adam J, Hatipoglu E, O'Flaherty L, Ternette N, Sahgal N, Lockstone H, Baban D, Nye E, Stamp GW, Wolhuter K, Stevens M, Fischer R, Carmeliet P, Maxwell PH, Pugh CW, Frizzell N, Soga T, Kessler BM, El-Bahrawy M, Ratcliffe PJ, Pollard PJ. Renal cyst formation in Fh1-deficient mice is independent of the Hif/Phd pathway: Roles for fumarate in Keap1 succination and Nrf2 signaling. Cancer Cell. 2011; 20:524-537. [PubMed: 22014577]

Alderson NL, Wang YP, Blatnik M, Frizzell N, Walla MD, Lyons TJ, Alt N, Carson JA, Nagai R, Thorpe SR, Baynes JW. S-(2-succinyl) cysteine: A novel chemical modification of tissue proteins by a krebs cycle intermediate. Arch Biochem Biophys. 2006; 450:1-8. [PubMed: 16624247]

Alt N, Carson JA, Alderson NL, Wang YP, Nagai R, Henle T, Thorpe SR, Baynes JW. Chemical modification of muscle protein in diabetes. Arch Biochem Biophys. 2004; 425:200-206. [PubMed: 15111128]

Ashrafian H, Czibik G, Bellahcene M, Aksentijevic D, Smith AC, Mitchell SJ, Dodd MS, Kirwan J, Byrne JJ, Ludwig C, Isackson H, Yavari A, Stottrup NB, Contractor H, Cahill TJ, Sahgal N, Ball DR, Birkler RID, Hargreaves L, Tennant DA, Land J, Lygate CA, Johannsen M, Kharbanda RK, Neubauer S, Redwood C, de Cabo R, Ahmet I, Talan M, Gunther UL, Robinson AJ, Viant MR, Pollard PJ, Tyler DJ, Watkins H. Fumarate is cardioprotective via activation of the Nrf2 antioxidant pathway. Cell Metab. 2012; 15:361-371. [PubMed: 22405071]

Bardella C, El-Bahrawy M, Frizzell N, Adam J, Ternette N, Hatipoglu E, Howarth K, O'Flaherty L, Roberts I, Turner G, Taylor J, Giaslakiotis K, Macaulay VM, Harris AL, Chandra A, Lehtonen HJ, Launonen V, Aaltonen LA, Pugh CW, Mihai R, Trudgian D, Kessler B, Baynes JW, Ratcliffe PJ, Tomlinson IP, Pollard PJ. Aberrant succination of proteins in fumarate hydratase-deficient mice and hlrcc patients is a robust biomarker of mutation status. J Pathol. 2011; 225:4-11. [PubMed: 21630274]

Bedhomme M, Adamo M, Marchand CH, Couturier J, Rouhier N, Lemaire SD, Zaffagnini M, Trost P. Glutathionylation of cytosolic glyceraldehyde-3-phosphate dehydrogenase from the model plant Arabidopsis thaliana is reversed by both glutaredoxins and thioredoxins in vitro. Biochem J. 2012; 445:337-347. [PubMed: 22607208]

Beltran L, Cutillas P. Advances in phosphopeptide enrichment techniques for phosphoproteomics. Amino Acids. 2012; 43:1009-1024. [PubMed: 22821267]

Blatnik M, Frizzell N, Thorpe SR, Baynes JW. Inactivation of glyceraldehyde-3-phosphate dehydrogenase by fumarate in diabetes-Formation of S-(2-succinyl)cysteine, a novel chemical modification of protein and possible biomarker of mitochondrial stress. Diabetes. 2008; 57:41-49. [PubMed: 17934141]

Blatnik M, Thorpe SR, Baynes JW. Succination of proteins by fumarate. Ann N YAcad Sci. 2008; 1126:272-275.

Brock JWC, Hinton DJS, Cotham WE, Metz TO, Thorpe SR, Baynes JW, Ames JM. Proteomic analysis of the site specificity of glycation and carboxymethylation of ribonuclease. J Proteome Res. 2003; 2:506-513. [PubMed: 14582647]

Brownlee M. The pathobiology of diabetic complications-A unifying mechanism. Diabetes. 2005; 54:1615-1625. [PubMed: 15919781]

Chang LC, Huang KC, Wu YW, Kao HL, Chen CL, Lai LP, Hwang JJ, Yang WS. The clinical implications of blood adiponectin in cardiometabolic disorders. J Formos Med Assoc. 2009; 108:353-366. [PubMed: 19443289]

Cross JV, Templeton DJ. Regulation of signal transduction through protein cysteine oxidation. Antioxid Redox Signal. 2006; 8:1819-1827. [PubMed: 16987034]

de Ferranti S, Mozaffarian D. The perfect storm: Obesity, adipocyte dysfunction, and metabolic consequences. Clin Chem. 2008; 54:945-955. [PubMed: 18436717]

Eng JK, McCormack AL, Yates JR. An approach to correlate tandem mass spectral data of peptides with amino acid sequences in a protein database. J Am Soc Mass Spectrom. 1994; 5:976-989. [PubMed: 24226387]

Frayn KN, Humphreys SM, Coppack SW. Fuel selection in white adipose-tissue. Proc Nutr Soc. 1995; 54:177-189. [PubMed: 7568252] 
Frizzell N, Rajesh M, Jepson MJ, Nagai R, Carson JA, Thorpe SR, Baynes JW. Succination of thiol groups in adipose tissue proteins in diabetes succination inhibits polymerization and secretion of adiponectin. J Biol Chem. 2009; 284:25772-25781. [PubMed: 19592500]

Frizzell N, Lima M, Baynes JW. Succination of proteins in diabetes. Free Radic Res. 2011; 45:101109. [PubMed: 20964553]

Frizzell N, Thomas SA, Carson JA, Baynes JW. Mitochondrial stress causes increased succination of proteins in adipocytes in response to glucotoxicity. Biochem J. 2012; 445:247-254. [PubMed: 22524437]

Ghoreschi K, Bruck J, Kellerer C, Deng CS, Peng HY, Rothfuss O, Hussain RZ, Gocke AR, Respa A, Glocova I, Valtcheva N, Alexander E, Feil S, Feil R, Schulze-Osthoff K, Rupec RA, Lovett-Racke AE, Dringen R, Racke MK, Rocken M. Fumarates improve psoriasis and multiple sclerosis by inducing type II dendritic cells. J Exp Med. 2011; 208:2291-2303. [PubMed: 21987655]

Giannessi D, Maltinti M, Del Ry S. Adiponectin circulating levels: A new emerging biomarker of cardiovascular risk. Pharmacol Res. 2007; 56:459-467. [PubMed: 18029194]

Goh SY, Cooper ME. The role of advanced glycation end products in progression and complications of diabetes. J Clin Endocrinol Metab. 2008; 93:1143-1152. [PubMed: 18182449]

Gundlach HG, Stein WH, Moore S. The nature of the amino acid residues involved in the inactivation of ribonuclease by iodoacetate. J Biol Chem. 1959; 234:1754-1760. [PubMed: 13672958]

Haynes, WM., editor. CRC Handbook of Chemistry and Physics. 93. Cleveland, Ohio, USA: Chemical Rubber Company; 2012. (online at: http://www.hbcpnetbase.com/)

Hu WT, Tedesco S, Faedda R, Petrone G, Cacciola SO, O'Keefe A, Sheehan D. Covalent selection of the thiol proteome on activated thiol sepharose: A robust tool for redox proteomics. Talanta. 2010; 80:1569-1575. [PubMed: 20082816]

Ishii T, Tatsuda E, Kumazawa S, Nakayama T, Uchida K. Molecular basis of enzyme inactivation by an endogenous electrophile 4-hydroxy-2-nonenal: Identification of modification sites in glyceraldehyde-3-phosphate dehydrogenase. Biochemistry. 2003; 42:3474-3480. [PubMed: 12653551]

Kallen CH, Greevenbroek MJ, Stehouwer CA, Schalkwijk C. Endoplasmic reticulum stress-induced apoptosis in the development of diabetes: Is there a role for adipose tissue and liver? Apoptosis. 2009; 14:1424-1434. [PubMed: 19757063]

Kanapin A, Batalov S, Davis MJ, Gough J, Grimmond S, Kawaji H, Magrane M, Matsuda H, Schonbach C, Teasdale RD, Yuan Z, Grp RG, Memebers GSL. Mouse proteome analysis. Genome Res. 2003; 13:1335-1344. [PubMed: 12819131]

Kettenhofen NJ, Wood MJ. Formation, reactivity, and detection of protein sulfenic acids. Chem Res Toxicol. 2010; 23:1633-1646. [PubMed: 20845928]

Kim, S.; Pevzner, P. MS-GF+: Universal and sensitive database search engine for mass spectrometry. 60th American Society for Mass Spectrometry Conference; Vancouver, Canada. 2012.

Kim S, Gupta N, Pevzner PA. Spectral probabilities and generating functions of tandem mass spectra: A strike against decoy databases. J Proteome Res. 2008; 7:3354-3363. [PubMed: 18597511]

Kim S, Mischerikow N, Bandeira N, Navarro JD, Wich L, Mohammed S, Heck AJR, Pevzner PA. The generating function of CID, ETD, and CID/ETD pairs of tandem mass spectra: Applications to database search. Mol Cell Proteomics. 2010; 9:2840-2852. [PubMed: 20829449]

Lai RK, Goldman P. Organic-acid profiling in adipocyte differentiation of 3T3-F442A cellsIncreased production of krebs cycle acid metabolites. Metab Clin Exp. 1992; 41:545-547. [PubMed: 1588836]

Lin Y, Berg AH, Iyengar P, Lam TKT, Giacca A, Combs TP, Rajala MW, Du XL, Rollman B, Li WJ, Hawkins M, Barzilai N, Rhodes CJ, Fantus IG, Brownlee M, Scherer PE. The hyperglycemiainduced inflammatory response in adipocytes-The role of reactive oxygen species. J Biol Chem. 2005; 280:4617-4626. [PubMed: 15536073]

Linker RA, Lee D-H, Ryan S, van Dam AM, Conrad R, Bista P, Zeng W, Hronowsky X, Buko A, Chollate S, Ellrichmann G, Brück W, Dawson K, Goelz S, Wiese S, Scannevin RH, Lukashev M, Gold R. Fumaric acid esters exert neuroprotective effects in neuroinflammation via activation of the Nrf2 antioxidant pathway. Brain. 2011; 134:678-692. [PubMed: 21354971] 
Liu ML, Liu F. Transcriptional and post-translational regulation of adiponectin. Biochem J. 2010; 425:41-52. [PubMed: 20001961]

Liu M, Zhou LJ, Xu AM, Lam KSL, Wetzel MD, Xiang RH, Zhang JJ, Xin XB, Dong LQ, Liu F. A disulfide-bond a oxidoreductase-like protein (DSBA-l) regulates adiponectin multimerization. Proc Natl Acad Sci USA. 2008; 105:18302-18307. [PubMed: 19011089]

Livesay EA, Tang K, Taylor BK, Buschbach MA, Hopkins DF, LaMarche BL, Zhao R, Shen Y, Orton DJ, Moore RJ, Kelly RT, Udseth HR, Smith RD. Fully automated four-column capillary LC-MS system for maximizing throughput in proteomic analyses. Anal Chem. 2007; 80(1):294-302. [PubMed: 18044960]

Maller C, Schröder E, Eaton P. Glyceraldehyde 3-phosphate dehydrogenase is unlikely to mediate hydrogen peroxide signaling: Studies with a novel anti-dimedone sulfenic acid antibody. Antixoxid Redox Signal. 2011; 14:49-60.

Mayampurath AM, Jaitly N, Purvine SO, Monroe ME, Auberry KJ, Adkins JN, Smith RD. Deconmsn: A software tool for accurate parent ion monoisotopic mass determination for tandem mass spectra. Bioinformatics. 2008; 24:1021-1023. [PubMed: 18304935]

Merkley ED, Anderson BJ, Park J, Belchik SM, Shi L, Monroe ME, Smith RD, Lipton MS. Detection and identification of heme c-modified peptides by histidine affinity chromatography, highperformance liquid chromatography-mass spectrometry, and database searching. J Proteome Res. 2012; 11:6147-6158. [PubMed: 23082897]

Mitsuishi Y, Motohashi H, Yamamoto M. The Keap1-Nrf2 system in cancers: Stress response and anabolic metabolism. Front Oncol. 2012; 2:200. [PubMed: 23272301]

Mitsuishi Y, Taguchi K, Kawatani Y, Shibata T, Nukiwa T, Aburatani H, Yamamoto M, Motohashi H. Nrf2 redirects glucose and glutamine into anabolic pathways in metabolic reprogramming. Cancer Cell. 2012; 22:66-79. [PubMed: 22789539]

Mohammed S, Heck AJR. Strong cation exchange (SCX) based analytical methods for the targeted analysis of protein post-translational modifications. Curr Opin Biotechnol. 2011; 22:9-16. [PubMed: 20926283]

Mostafa A, Randell E, Vasdev S, Gill V, Han Y, Gadag V, Raouf A, El Said H. Plasma protein advanced glycation end products, carboxymethyl cysteine, and carboxyethyl cysteine, are elevated and related to nephropathy in patients with diabetes. Mol Cell Biochem. 2007; 302:35-42. [PubMed: 17318407]

Mrowietz U, Altmeyer P, Bieber T, Röcken M, Schopf RE, Sterry W. Treatment of psoriasis with fumaric acid esters (Fumaderm). J Dtsch Dermatol Ges. 2007; 5:716-717. [PubMed: 17659047]

Nagai R, Brock JW, Blatnik M, Baatz JE, Bethard J, Walla MD, Thorpe SR, Baynes JW, Frizzell N. Succination of protein thiols during adipocyte maturation-A biomarker of mitochondrial stress. $\mathrm{J}$ Biol Chem. 2007; 282:34219-34228. [PubMed: 17726021]

Nguyen T, Nioi P, Pickett CB. The Nrf2-antioxidant response element signaling pathway and its activation by oxidative stress. J Biol Chem. 2009; 284:13291-13295. [PubMed: 19182219]

Ooi A, Wong JC, Petillo D, Roossien D, Perrier-Trudova V, Whitten D, Min BWH, Tan MH, Zhang ZF, Yang XMJ, Zhou M, Gardie B, Molinie V, Richard S, Tan PH, Teh BT, Furge KA. An antioxidant response phenotype shared between hereditary and sporadic type 2 papillary renal cell carcinoma. Cancer Cell. 2011; 20:511-523. [PubMed: 22014576]

Papadopoulou A, D’Souza M, Kappos L, Yaldizli O. Dimethyl fumarate for multiple sclerosis. Expert Opin Invest Drugs. 2010; 19:1603-1612.

Pollard PJ, Brière JJ, Alam NA, Barwell J, Barclay E, Wortham NC, Hunt T, Mitchell M, Olpin S, Moat SJ, Hargreaves IP, Heales SJ, Chung YL, Griffiths JR, Dalgleish A, McGrath JA, Gleeson MJ, Hodgson SV, Poulsom R, Rustin P, Tomlinson IPM. Accumulation of krebs cycle intermediates and over-expression of HIF1a in tumours which result from germline FH and SDH mutations. Hum Mol Genet. 2005; 14:2231-2239. [PubMed: 15987702]

Pollard PJ, Spencer-Dene B, Shukla D, Howarth K, Nye E, El-Bahrawy M, Deheragoda M, Joannou M, McDonald S, Martin A, Igarashi P, Varsani-Brown S, Rosewell I, Poulsom R, Maxwell P, Stamp GW, Tomlinson IPM. Targeted inactivation of FH1 causes proliferative renal cyst development and activation of the hypoxia pathway. Cancer Cell. 2007; 11:311-319. [PubMed: $17418408]$ 
Schmidt MM, Dringen R. Fumaric acid diesters deprive cultured primary astrocytes rapidly of glutathione. Neurochem Int. 2010; 57:460-467. [PubMed: 20096739]

Schubert U, Anton LC, Gibbs J, Norbury CC, Yewdell JW, Bennink JR. Rapid degradation of a large fraction of newly synthesized proteins by proteasomes. Nature. 2000; 404:770-774. [PubMed: 10783891]

Shah A, Mehta N, Reilly MP. Adipose inflammation, insulin resistance, and cardiovascular disease. J Parenter Enteral Nutr. 2008; 32:638-644.

Ternette N, Yang M, Laroyia M, O’Flaherty L, Wolhuter K, Kato K, Fischer R, Kessler BM, Lappin T, Frizzell N, Soga T, Adam J, Pollard PJ. Inhibition of mitochondrial aconitase by succination in fumarate hydratase deficiency. Cell Rep. 2013; 28:689-700. [PubMed: 23499446]

Thomas SA, Storey KB, Baynes JW, Frizzell N. Tissue distribution of S-(2-succino)cysteine (2SC), a biomarker of mitochondrial stress in obesity and diabetes. Obesity. 2012; 20:263-269. [PubMed: 22134201]

Townsend DM. S-glutathionylation: Indicator of cell stress and regulator of the unfolded protein response. Mol Interv. 2007; 7:313-324. [PubMed: 18199853]

Van Gaal LF, Mertens IL, De Block CE. Mechanisms linking obesity with cardiovascular disease. Nature. 2006; 444:875-880. [PubMed: 17167476]

Washburn MP, Wolters D, Yates JR. Large-scale analysis of the yeast proteome by multidimensional protein identification technology. Nat Biotechnol. 2001; 19:242-247. [PubMed: 11231557]

Webster KA, Prentice H, Bishopric NH. Oxidation of zinc finger transcription factors: Physiological consequences. Antioxid Redox Signal. 2001; 3:535-548. [PubMed: 11554443]

Wood IS, de Heredia FP, Wang BH, Trayhurn P. Cellular hypoxia and adipose tissue dysfunction in obesity. Proc Nutr Soc. 2009; 68:370-377. [PubMed: 19698203]

Yang F, Shen YF, Camp DG, Smith RD. High-pH reversed-phase chromatography with fraction concatenation for 2D proteomic analysis. Expert Rev Proteomics. 2012a; 9:129-134. [PubMed: 22462785]

Yang M, Soga T, Pollard PJ, Adam J. The emerging role of fumarate as an oncometabolite. Front Oncol. 2012b; 2:85. [PubMed: 22866264]

Yin J, Gao Z, He Q, Zhou D, Guo Z, Ye J. Role of hypoxia in obesity-induced disorders of glucose and lipid metabolism in adipose tissue. Am J Physiol Endocrinol Metab. 2009; 296:E333-E342. [PubMed: 19066318]

Zhang D. The Nrf2-Keap1-ARE signaling pathway: The regulation and dual function of Nrf2 in cancer. Antioxid Redox Signaling. 2010; 13:1623-1626.

Zhang QB, Tang N, Brock JWC, Mottaz HM, Ames JM, Baynes JW, Smith RD, Metz TO. Enrichment and analysis of nonenzymatically glycated peptides: Boronate affinity chromatography coupled with electron-transfer dissociation mass spectrometry. J Proteome Res. 2007; 6:2323-2330. [PubMed: 17488106] 


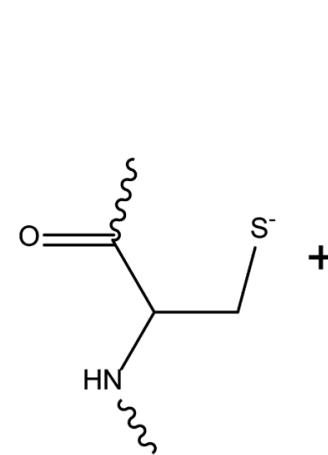

Protein-SH

(Thiolate)

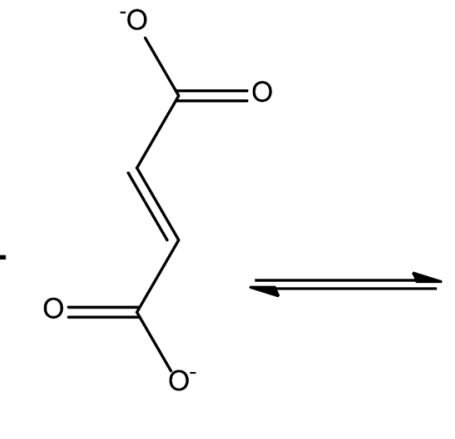

Fumarate

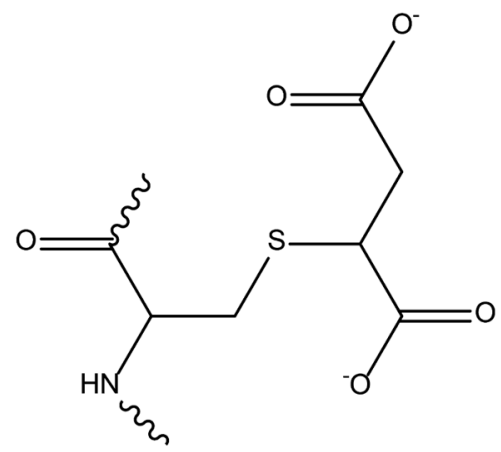

2-(S-succino) cysteine

FIGURE 1.

Formation of 2-( $S$-succino)cysteine (2SC) by reaction of fumarate with cysteine residues in protein. 

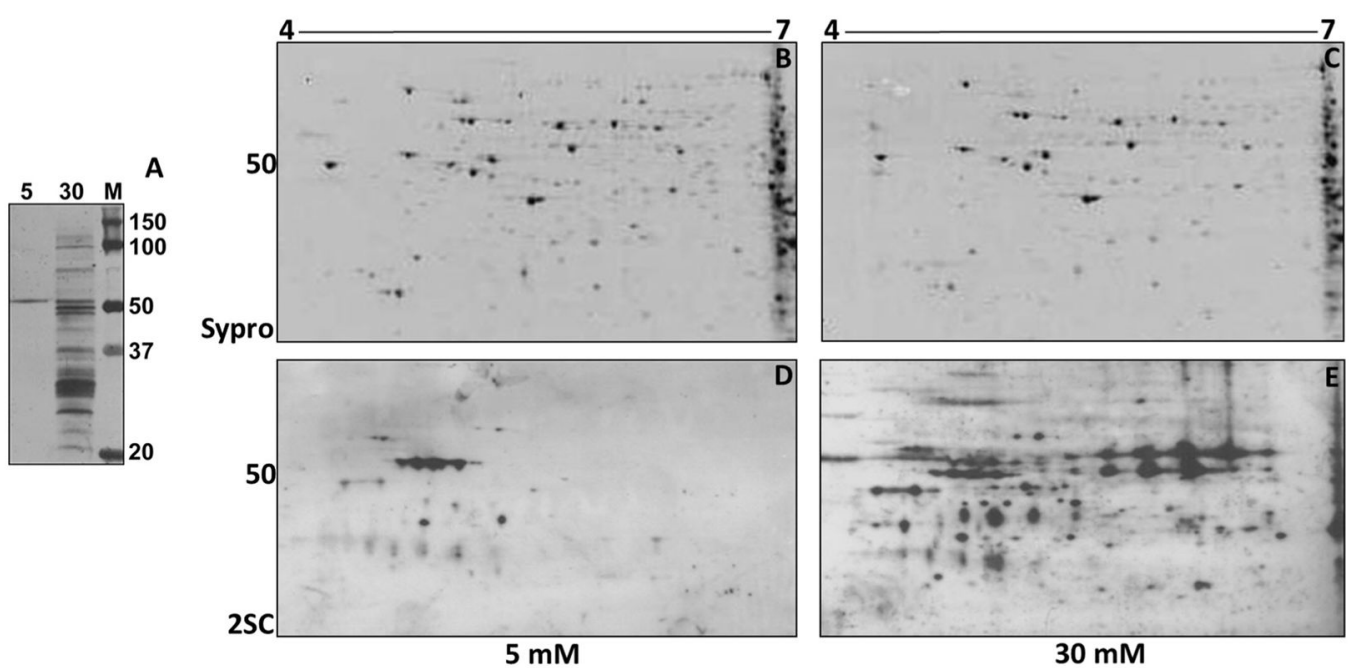

FIGURE 2.

Detection of succinated proteins in adipocytes. A: Total cell lysates (30 $\mu \mathrm{g}$ protein) from adipocytes cultured in 5 or $30 \mathrm{mM}$ glucose for 4 days were separated by 1D PAGE. 2SCmodified proteins were detected using polyclonal anti-2SC antibody. $\mathrm{M}$ indicates marker lane and numbers at right indicate molecular weights of marker proteins. B-E: Further separation of $150 \mu \mathrm{g}$ protein from adipocytes grown in 5 or $30 \mathrm{mM}$ glucose was analyzed by 2D gel electrophoresis across a 4-7 pH range. Duplicate gels were either stained with Sypro Ruby to observe total protein (B,C) or transferred to PVDF and immunoblotted with anti-2SC antibody to detect succinated proteins (D,E). Protein succination was increased in adipocytes cultured in $30 \mathrm{mM}$ glucose (E) versus $5 \mathrm{mM}$ (D) although there were no major changes observed in the Sypro total protein profile $(B, C)$. Reprinted with permission from Frizzell et al. (2012), copyright 2012 the Biochemical Society. 


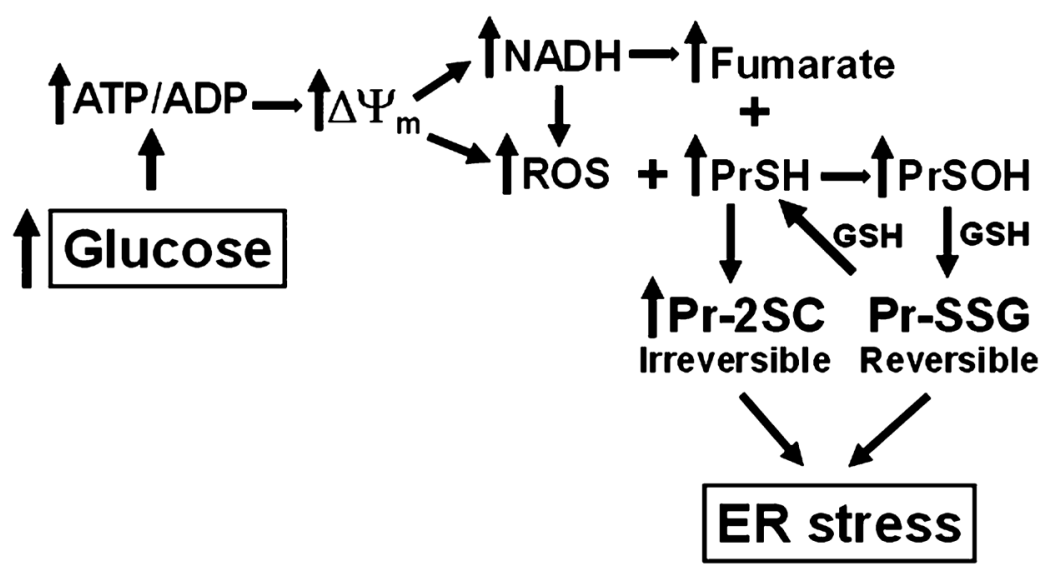

FIGURE 3.

Pathway leading to succination of proteins. This scheme outlines a proposed sequence of events resulting from high glucose concentration (glucotoxicity) in type 2 diabetes including the glucose-induced increase in ATP/ADP, $\Delta \Psi_{\mathrm{m}}, \mathrm{NADH} / \mathrm{NAD}^{+}$, and fumarate. Fumarate reacts directly with protein to form $2 \mathrm{SC}$. Alternatively, protein is oxidized by ROS, generating a sulfenic acid, which is reversed by GSH. In this scheme, irreversible succination competes with reversible glutathionylation of protein. Accumulation of succinated and glutathionylated chaperone proteins in the endoplasmic reticulum inhibits protein folding, assembly, post-translational modification, transport and secretion, leading to ER stress. Excessive ER stress, exceeding the capacity of the Unfolded Protein Response (UPR), leads to apoptosis. Reprinted with permission from Frizzell, Lima, and Baynes (2011), copyright 2011 Informa Healthcare. 


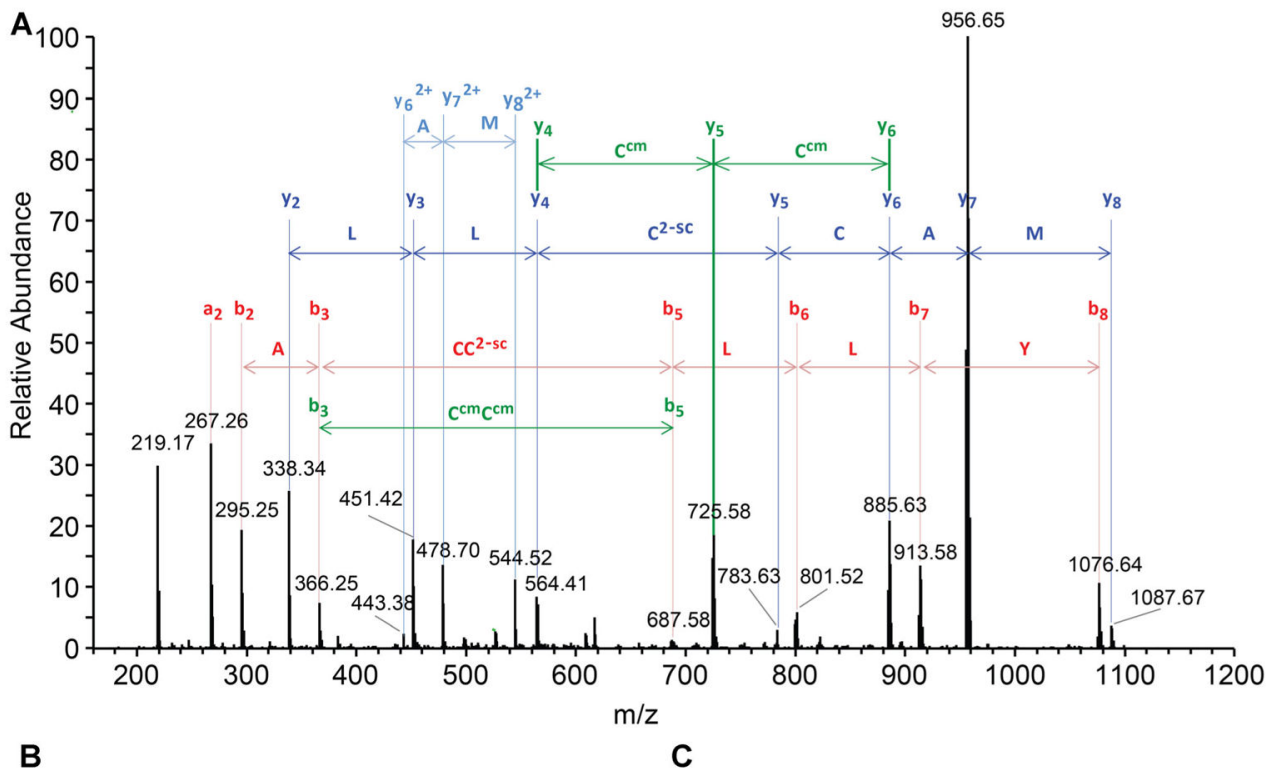

$B$

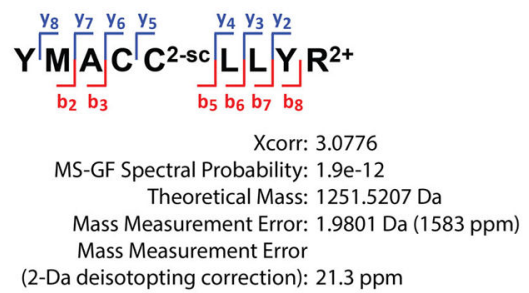

C

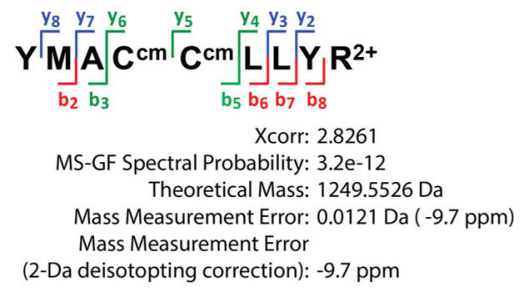

FIGURE 4.

Distinguishing succination $\left(\mathrm{C}_{4} \mathrm{O}_{4} \mathrm{H}_{4}, 116.011 \mathrm{Da}\right)$ from double carbamidomethylation $(2 \times$ $\left.\mathrm{C}_{2} \mathrm{H}_{3} \mathrm{NO}, 2 \times 57.021 \mathrm{Da}=114.042 \mathrm{Da}\right)$. A: Collision-induced dissociation spectrum of the doubly charged peptide YMACCLLYR from mouse alpha-tubulin, from LC-ESI-MS analysis of a tryptic digest of mouse adipocyte proteins alkylated with iodoacetamide. The peptide is modified either by succination on the second cysteine residue, or by carbamidomethylation on both of the two cysteine residues. The $b$-ion series is shown in red and the $y$-ion series in dark blue. A doubly charged $y$-ion series is shown in light blue.

Alternative peak assignments supporting double carbamidomethylation are shown in green. The spectrum was recorded in the ion trap mass analyzer of a Thermo Scientific LTQ Orbitrap mass spectrometer. B: Summary of observed fragmentation and database search scores for the succinated peptide. C: Results for the doubly carbamidomethylated peptide. Xcorr is the Xcorr score from Sequest (Eng, McCormack, \& Yates, 1994); MS-GF spectral probability is the probability that a better-scoring peptide exists for this spectrum, calculated by the MS-GF software (Kim, Gupta, \& Pevzner, 2008; Kim et al., 2010). Note that while the succinated peptide has better MS-GF and Xcorr scores, the precursor mass information supports the identification of the peptide as the doubly carbamidomethylated species. In addition, the prominent peak at $\mathrm{m} / \mathrm{z} \sim 725$ is only explained by double carbamidomethylation. The "deisotoping correction" is automatically applied on our pipeline in cases where the difference between theoretical and observed mass is very close to exactly 1 or $2 \mathrm{Da}$, and corrects for whole-Dalton errors in the observed mass that arise from occasional failures of the DeconMSN (Mayampurath et al., 2008) algorithm in 
identifying the monoisotopic mass. Here, the automatically applied correction is inappropriate, since the $\sim 2 \mathrm{Da}$ shift comes from the mass difference between succination and double carbamidomethylation. 


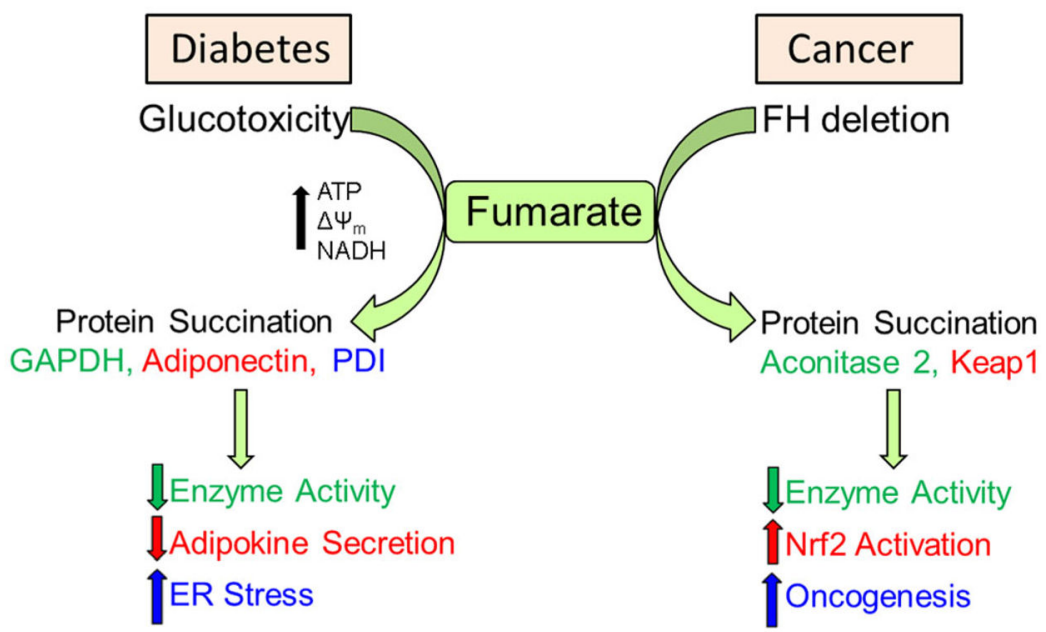

FIGURE 5.

Protein succination in diabetes and cancer. Protein succination increases in the diabetic adipocyte when glucotoxicity driven mitochondrial stress leads to an increase in mitochondrial membrane potential $\left(\Delta \Psi_{\mathrm{m}}\right)$ and $\mathrm{NADH}: \mathrm{NAD}^{+}$, resulting in increased fumarate. The rise in fumarate leads to increased protein succination on a number of targets including GAPDH, adiponectin, and protein disulfide isomerase (PDI) resulting in decreased GAPDH activity, reduced adiponectin secretion and increased endoplasmic reticulum stress (ER stress), respectively. Independent of glucotoxicity, cancers which are derived from deletion or mutation of fumarate hydratase $(\mathrm{FH})$ also result in elevated fumarate levels and subsequent protein succination. Aconitase 2 and Keap1 are succinated targets in FHdeficient cells, resulting in Nrf2 activation and reduced Aconitase 2 activity, both of which are associated with oncogenesis in this model. 


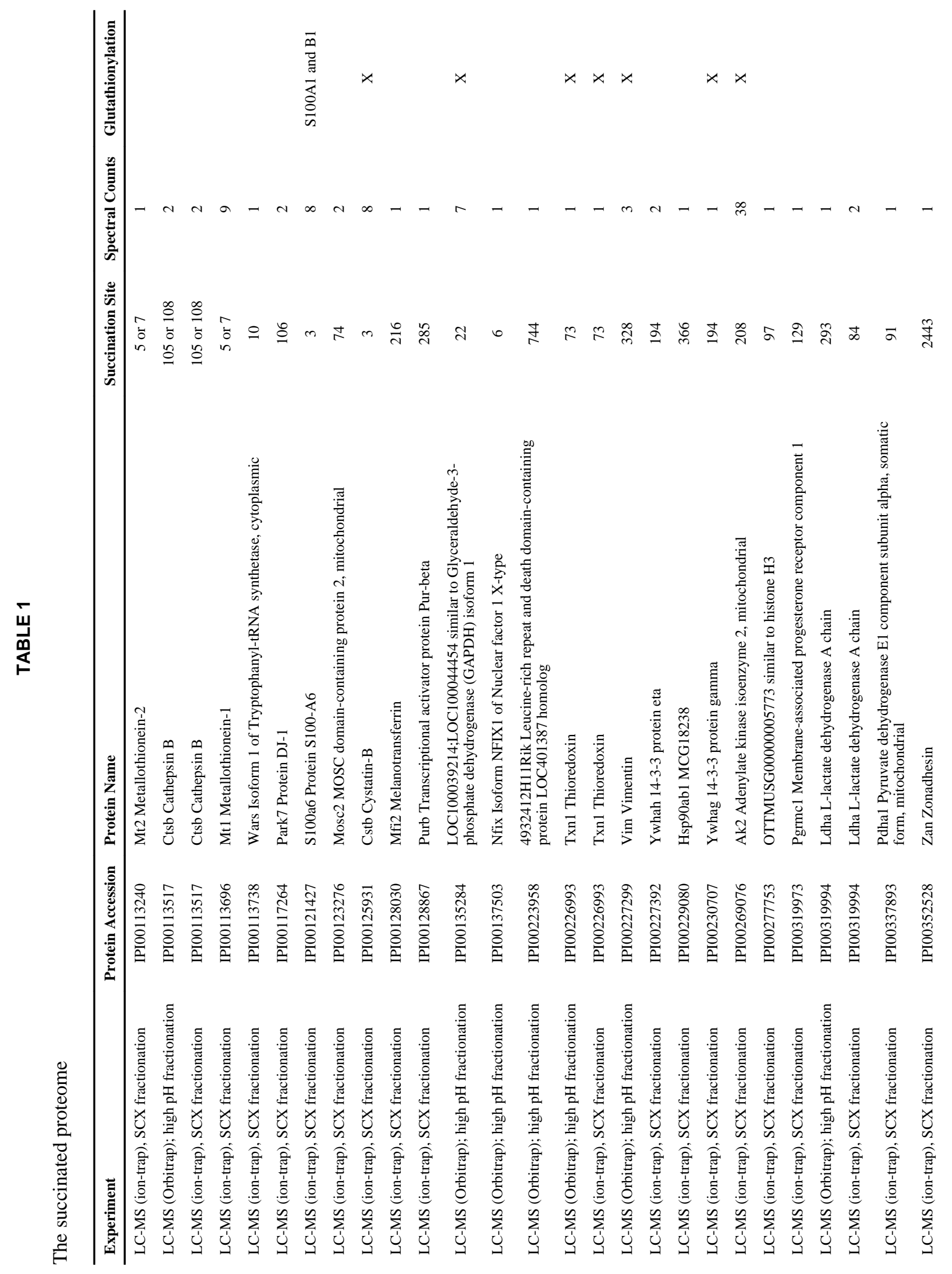

Mass Spectrom Rev. Author manuscript; available in PMC 2014 May 29. 


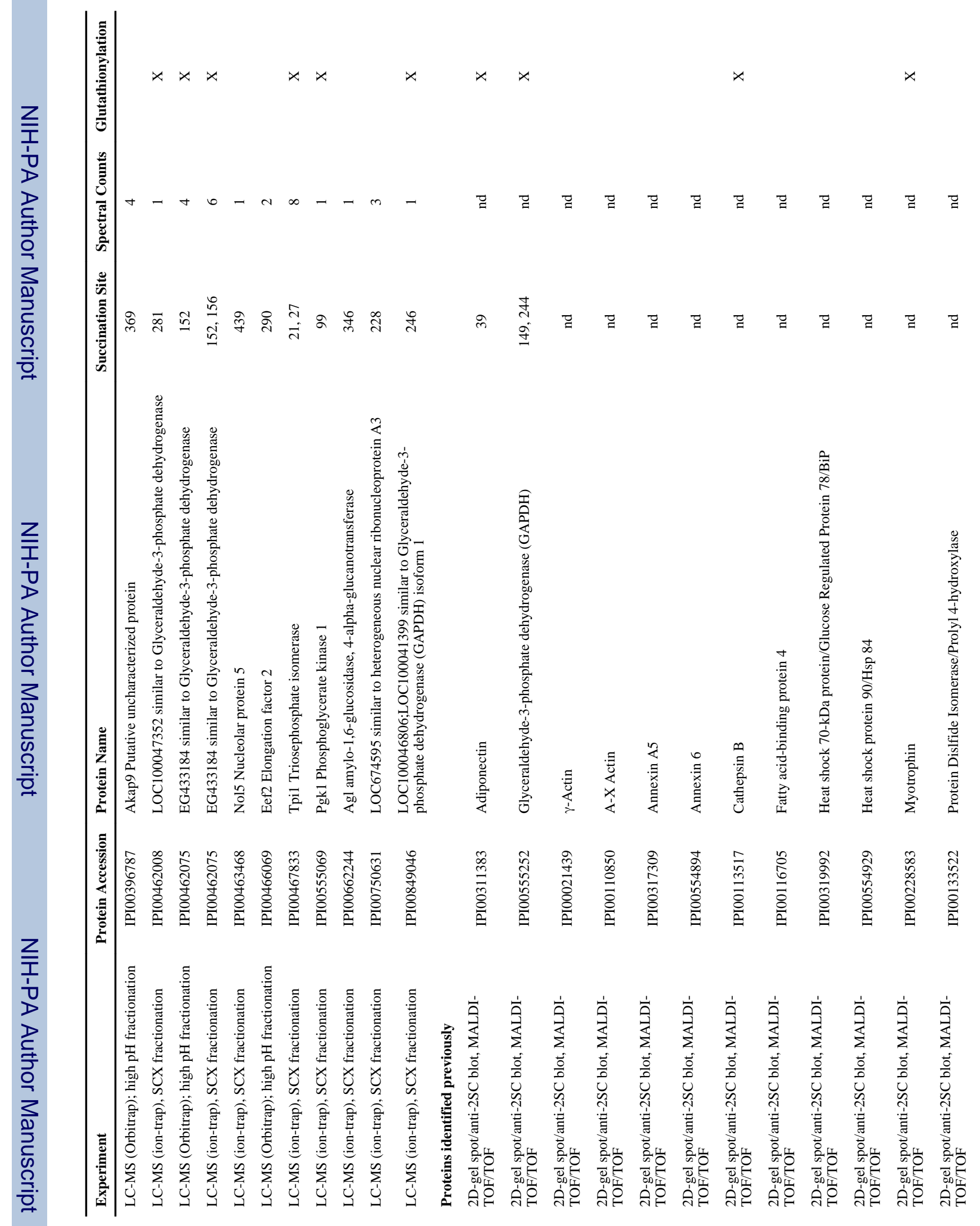


Merkley et al.

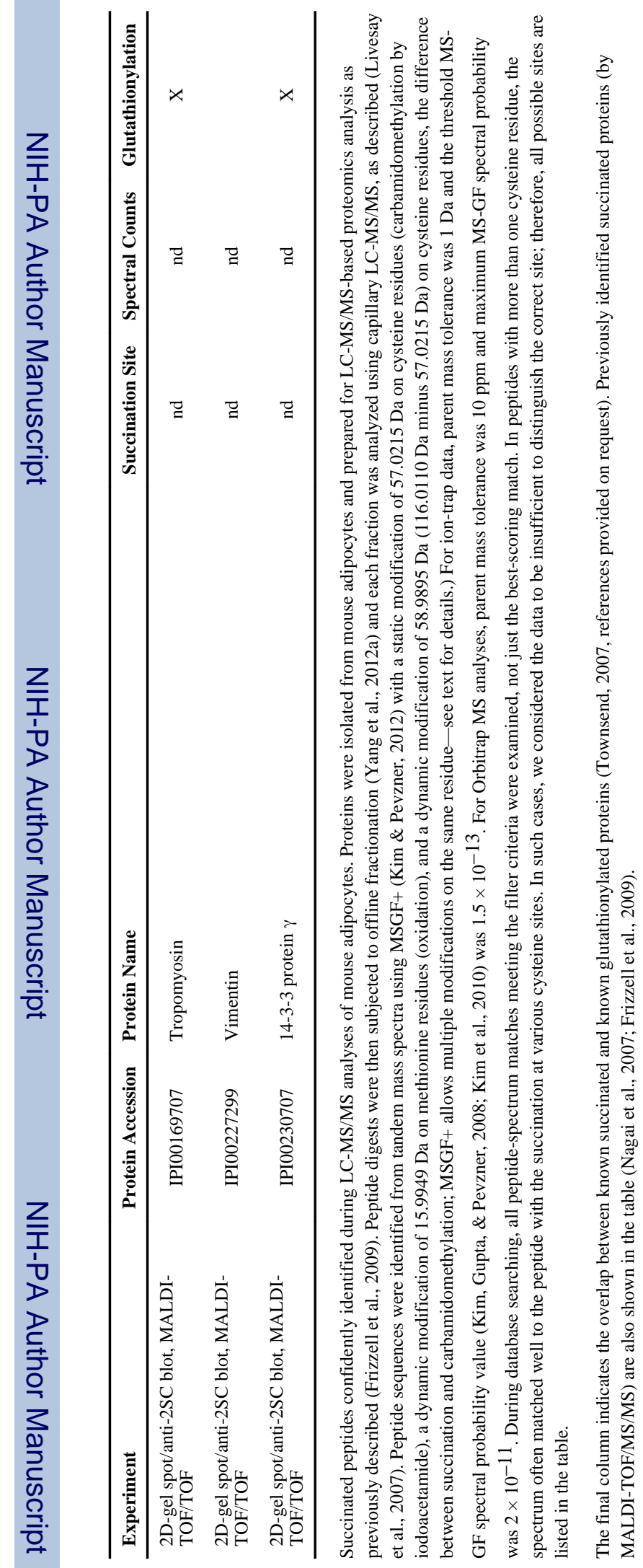

Mass Spectrom Rev. Author manuscript; available in PMC 2014 May 29. 